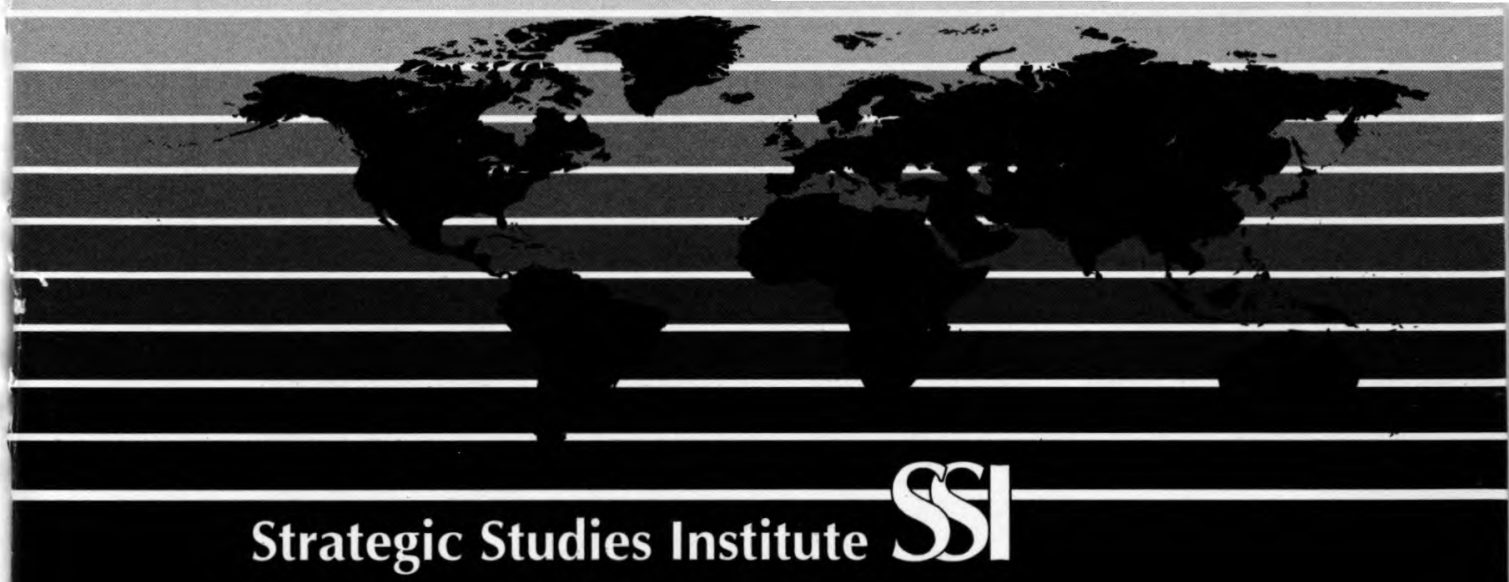

\title{
DEVELOPING ADAPTIVE LEADERS: THE CRUCIBLE EXPERIENCE OF OPERATION IRAQI FREEDOM
}

\author{
Leonard Wong
}

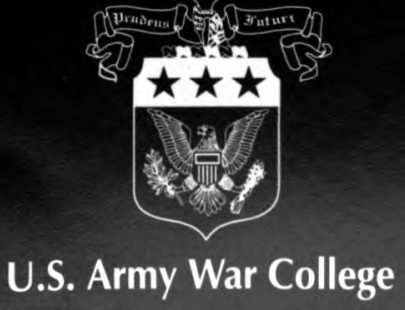

